\title{
Student Problem Solving Analysis by Step John Dewey Reviewed from Learning Style
}

\author{
Ni Ummu Kulsum ${ }^{1}$, Kristayulita ${ }^{2}$ \\ ${ }^{1,2}$ Mathematics Education Department, Islamic University of Mataram, Indonesia \\ ${ }^{1}$ niummukulsum30@gmail.com, ${ }^{2}$ kristayulita@uinmataram.ac.id
}

\section{Keywords: \\ Problem Solving; \\ John Dewey; \\ Learning Style.}

\begin{abstract}
ABSTRAK
This research aims to describe the student's mathematical problem solving based on John Dewey's step viewed by learning style. The subjects are 2 students with a visual learning style, 2 students with auditory learning style, and a student with kinaesthetic learning. The data was collected through a questionnaire of learning style, the test of mathematics problem solving, interview, and documentation. Then it was analyzed used Milles and Huberman model's data analyzed technique consist of data reduction, data display, and conclusion (verification). This research shows that: (1) the visual subject confronted the problem by reading the question silently in several times, the subject can't define the problem correctly, can't found the right solution so that calculating and the answer is not correct, and can't test consequences (looking back), (2) the auditory subject confronted the problem with reading the question in several times loudly, the subject can define the problem correctly, can found the right solution so that calculating and the answer correctly, and can't test consequences (looking back), (3) the kinesthetic subject confronted the problem with reading the question in several times, the subject can't define the problem correctly, can't found the right solution so that calculating and the answer is not correct, and can't test consequences (looking back).
\end{abstract}

\section{A. INTRODUCTION}

Problem solving is part of a very important mathematical curriculum. This is because students will gain experience in using the knowledge and skills they have to solve the problems that are not routine. The importance of problem solving in learning is also conveyed by the National Council of Teacher of Mathematics (NCTM). According to the NCTM (2000), the mathematical thinking process in mathematics learning includes five key standard competencies consisting of problem solving capabilities, reasoning ability, connection capabilities, communication capabilities and representation ability.

According to Lencher in Hartono (2014) stated that mathematical problems are a matter of mathematics whose completion strategy is not immediately visible, so that in its completion it requires the knowledge, skills, and understanding that has been learned. While Branca in Hartono (2014) states that problem solving can be interpreted into three different categories. First, problem solving as a focused goal of learning how to solve the problem. Secondly, solving the problem as a process that focuses on methods, procedures, strategies, and heuristics used in 
problem solving. Third, problem solving as a basic skill that one of them concerns the minimal skills that students have in mastering mathematics.

To solve the problem of mathematical necessary completion measures, or known by steps of mathematical troubleshooting. According to John Dewey in Jamin Carson (2007), the Troubleshooting steps consist of (1) Confront problem, (2) define problem, (3) inventory several solution, (4) conjecture consequence of solution, and (5) test consequences.

Research on solving students ' mathematical problems was conducted by Youwanda Lahinda and Jailani (2015). His research results showed that students with high levels of intelligence used identify subgoals and use formula strategies. While draw a sketch strategy is used by students with moderate and low level of intelligence. Another study was conducted by Vina Muthmainna Rianto, et al. (2017) concluded that students ' problem-solving skills based on John Dewey's theories on the upper group entered the high category, while in the middle and lower groups are in medium.

Students ' mathematical problem solving skills are influenced by several factors, including experience, student's initial knowledge, mathematical logical intelligence, motivation, thinking skills, mathematical appreciation, learning style, etc. This was strengthened by the research done by I Putu Eka Irawan et al. (2016), concluded that initial knowledge, mathematical logical intelligence, and mathematical appreciation were instrumental in the ability to solve mathematical problems. Another study by Fitria Rahmawati (2016) shows that the learning style and attention of students also affect the ability to solve mathematical problems. Therefore, mathematical problem solving skills can be improved through teaching ways that correspond to the learning style and attention of students.

According to Pritchard in Muhammad Yaumi (2013), learning styles are a particular way in which an individual can learn, learn how to, the preferred or best way to think, process information and demonstrate learning, or individual selected tools in acquiring knowledge and skills. In general there are three kinds of learning styles that are learning by looking (visual learning), learning by listening (auditory learning), and learning by doing (kinesthetic learning) (Nini Subini, 2011). The three learning styles are known as VAK learning Style (Visual, auditory, kinaesthetic).

Research on solving mathematical problems reviewed learning styles has been widely done. The research was done by Ristina Indrawati (2017) which concluded that the auditory subject can understand the problem and make the planning well, while the visual subject is less able to understand the problem so it affects the resulting answer, and the kinaesthetic subject feels jittery while reading so as not to focus on understanding the problem, this affects the answer that is less suitable to the desired outcome Another study conducted by Syaharuddin (2016) concluded that students with the highest visual and auditory learning style scores were able to solve the SPLDV problem given. Both studies use troubleshooting steps by G. Polya.

Based on the results of the research interview with one of the mathematics teachers in MTs, the Qur'an, obtained by the ability to solve mathematics problem in some classes VIII students still lacking. This can be known when students are given problem solving, many students who re-ask their teachers about their intent and completion steps. In addition to the results of the research conducted by Saint Arini et al. (2017), suggesting that out of 30 students, who had excellent problem-solving capabilities of $6.67 \%$ and students who had good problem-solving capabilities of $40 \%$.

Based on the above problems, namely (1) Learning style affects the ability to solve mathematical problems (Fitria Rahmawati, 2016); (2) Lack of students ' mathematical problem solving skills; and (3) Previous research on solving mathematical problems is reviewed from the learning style using the problem solving theory G. Polya (Ristina Indrawati, 2017; Syaharuddin, 2016), would need further research on solving students ' mathematical problems based on John Dewey's step reviewed from visual, auditory, and kinaesthetic learning styles. This research is very important because it can know the learning style as well as the ability to solve mathematics problems that students have, so it can help teachers to implement a teaching strategy that adjusts to the learning style that the students have. 


\section{B. METHODS}

The approach used in this study is a qualitative approach with a type of descriptive case study. A five-student study subject consisting of two visually-learned students, two auditory study-style students, and 1 student of kinaesthetic learning. The research subject is selected using the purposive sampling technique, which is a sampling technique with certain considerations. In the selection of research subjects, researchers also coordinate with mathematics teachers at research locations to determine the characteristics of students to be researched.

The main instrument in this research is its own researchers. Meanwhile, the supporting instruments consist of study style poll, math problem solving test, interview guideline, and video recorder. The study style poll used in this study was adopted from a learning style poll developed by Sonya Eka Santoso. The poll consists of 27 statements and each statement consists of three answer options. These three answers represent traits of one of the learning styles, answer A to represent a visual learning style, answer B represents auditory learning style, and answer $\mathrm{C}$ represents kinaesthetic learning style. The problem of mathematical troubleshooting tests in the study was developed by researchers themselves. Problem consists of one number and has been validated by two mathematics lecturers UIN Mataram and one mathematics teacher.

Researchers are collecting data by means of giving study style and test questions, conducting interviews on informant, and documentation. The data that has been obtained is then analyzed by the data analysis techniques of Miles and Hubberman models consisting of data reduction, data presentation, and conclusion withdrawal. To check the validity of the data in this study, researchers use triangulation. The type of triangulation used is triangulation technique/method. Triangulation technique means checking data and information obtained using data collection techniques vary from the same source. In this case, researchers use test techniques, interviews, and documentation to obtain data on students ' mathematical troubleshooting steps.

\section{RESULT AND DISCUSSION}

Data collection in this study began from the division of the Learning style poll to categorize students based on their learning style. The Learning style poll was given to 33 students consisting of 17 students of grade VIII A and 16 students of grade VIII B. Based on the results of analysis of learning style poll that has been given, then the acquisition of learning style students of classes VIII A and VIII B can be seen in Table 1.

Table 1. Acquisition of learning style students of class VIII A and VIII B

\begin{tabular}{|c|c|c|c|c|c|c|c|}
\hline \multirow[t]{2}{*}{ Class } & \multicolumn{6}{|c|}{ Learning Style } & \multirow[t]{2}{*}{ Total } \\
\hline & Visual & Auditory & Kinaesthetic & $\begin{array}{c}\text { Visual- } \\
\text { Auditory }\end{array}$ & $\begin{array}{c}\text { Visual- } \\
\text { Kinaesthetic }\end{array}$ & $\begin{array}{c}\text { Auditory- } \\
\text { Kinaesthetic }\end{array}$ & \\
\hline $\mathbf{A}$ & 8 & 7 & - & 1 & 1 & - & 17 \\
\hline B & 8 & 4 & 1 & 1 & - & 2 & 16 \\
\hline Total & 16 & 11 & 1 & 2 & 1 & 2 & 33 \\
\hline
\end{tabular}

According to the table above, it is known that class VIII students have a tendency to visually study a 16-person style, auditory learning style of 11 people, kinaesthetic learning style as much as 1 person, and the rest are combined with two learning styles.

The next activity is to provide questions on the problem solving math test in students of class VIII A and VIII B given to get data on solving problems of mathematics. The results of the poll and the test were selected five students as research subjects consisting of two visual subjects, two auditory subjects, and one kinaesthetic subject. The research subject selection uses purposive sampling techniques based on the completeness of students ' answers and the ease of 
obtaining information when interviewed. Researchers also coordinate with class VIII mathematics teachers in determining subjects that are able to provide clear information when interviewed. The five students as the subject of the study will be interviewed related to solving math problems based on John Dewey's steps. As for the students selected as the subject of research can be seen in Table 2 .

Tabel 2. Research subject

\begin{tabular}{cllcl}
\hline Initials & \multicolumn{1}{c}{ Subject } & Class & Gender & Learning Style \\
\hline $\mathrm{DR}$ & Visual Subject $1\left(\mathrm{SV}_{1}\right)$ & VIII B & $\mathrm{P}$ & Visual \\
\hline $\mathrm{AR}$ & Visual Subject $2\left(\mathrm{SV}_{2}\right)$ & VIII A & $\mathrm{P}$ & Visual \\
\hline $\mathrm{ZS}$ & Auditory Subject $1\left(\mathrm{SV}_{1}\right)$ & VIII A & $\mathrm{P}$ & Auditory \\
\hline $\mathrm{MF}$ & Auditory Subject $2\left(\mathrm{SV}_{2}\right)$ & VIII A & L & Auditory \\
\hline $\mathrm{MG}$ & Kinaesthetic Subject & VIII B & $\mathrm{P}$ & Kinaesthetic \\
\hline
\end{tabular}

Based on the results of the research, solving the mathematical problems of visual subjects, auditory, and kinaesthetic can be explained as follows:

\section{Mathematics Problem Solving Visual Subject}

a. Visual Subject 1

At confront the problem stage, the subject seems to feel difficulties with the problem given. It is characterized by the expression and mimics of the subject being long-thought. When faced with the question, the subject does not directly write the answer, but first read the question silently several times. At the definition of the problem, the subject of drawing the angle of the elbow and the caption on each side of the triangle is $34.4+1.6$ as high tower plus high Andi, then 39 as the distance of the binoculars Andi to ship A, and 45 as the distance binoculars Andi to the ship B. Then, the subject writes a question mark (?) under the $\mathrm{AB}$ side but the long description of the written side is incomplete and has not yet been able to define the problem entirely. At the discovery stage of the solution, the subject renders Pythagoras ' formula. The subject is still mistaken in understanding the problem so that the formula used is incomplete and precise. At the alleged consequence of the solution, the subject performs a calculation based on the solution found. The subject renders the number 84 as the length of the large sloped side of the triangle, which should be 45 . Additionally, the subject is erroneous in determining the root value of 5,960. Consequently, the answers are not yet precise. And at the test stage the alleged consequences of the solution, the subject does not write the check back step on the answer sheet. Based on the results of the interview, obtained information that the subject is re-checking by redrawing the triangle and recalculating. The answer to the test of visual subject 1 can be seen in Figure 1.

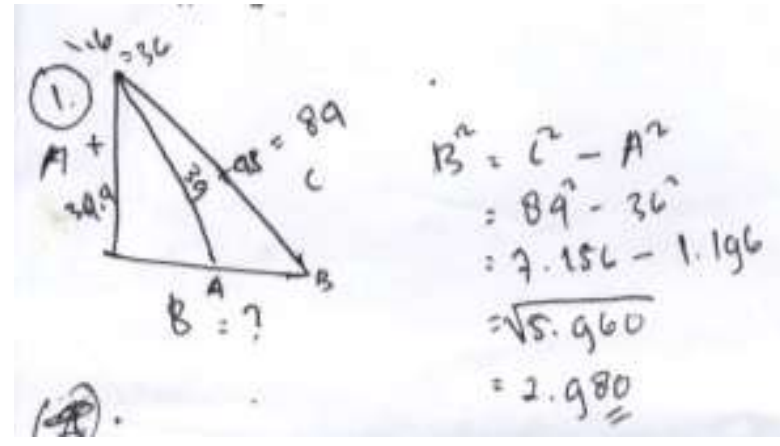

Figure 1. Visual Subject Answer 1 
b. Visual Subject 2

At confront the problem stage, the subject feels difficulties with the problem. It is according to the results of the documentation and interviews that illustrate that when faced with the question, the subject does not directly write the answer, but think first and read the question several times in the heart. At the definition of the problem, the subject of drawing the elbow-elbow along with the caption of the length of the triangle, which is $34.4 \mathrm{~m}$ tall as the tower height, and 39 as the length of the small triangles. The triangle and caption length are incomplete and have not yet been able to define the issue of the whole problem. At the discovery stage of the solution, the subject could not find the solution of the given problem. It is characterized by the absence of a formula or strategy written on the answer sheet. At the alleged consequences of the solution, the subject is unable to perform proper calculations because at the previous stage the subject did not find the exact solution of the given problem. And at the test stage of the consequences, the subject does not write a rechecking step towards the answers obtained. Based on the results of the interview, obtained information that the subject does not re-check the answer because of rush. The answer to the test of visual subject 2 can be seen in Figure 2 .

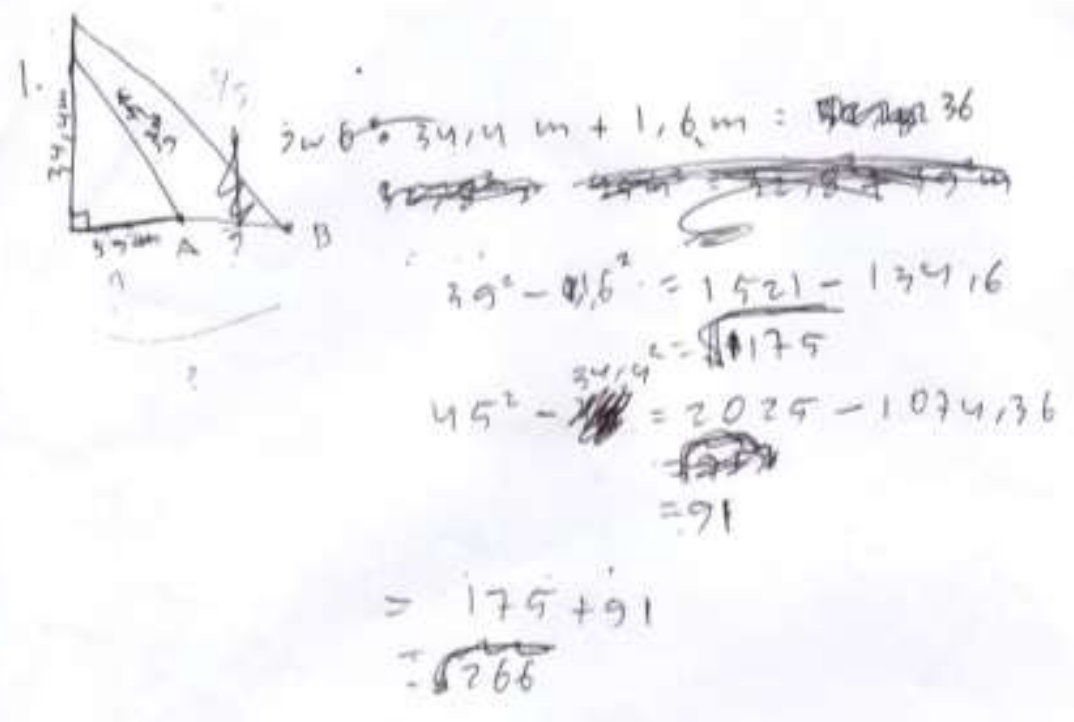

Figure 2. Visual Subject Answer 2

Based on analysis of the mathematical problems of visual subjects 1 and 2 that are displayed earlier, there can be similarities between visual subjects in resolving the problem. The mathematical problem solving visual subjects based on the steps John Dewey can be seen in Table 3.

Table 3. Visual Subject Mathematics Problem Solving

\begin{tabular}{|l|l|l|}
\hline \multicolumn{1}{|c|}{ Troubleshooting Steps } & \multicolumn{1}{|c|}{ Visual Subject 1 } & \multicolumn{1}{c|}{ Visual Subject 2 } \\
\hline Confront problem & $\begin{array}{l}\text { Read about several times in } \\
\text { her heart }\end{array}$ & Read about a few times \\
\hline Define problem & Cannot define a problem & Cannot define a problem \\
\hline Inventory several solution & Could not find solution & Could not find solution \\
\hline $\begin{array}{l}\text { Conjecture consequence of } \\
\text { solution }\end{array}$ & $\begin{array}{l}\text { Cannot perform calculations } \\
\text { based on solutions found }\end{array}$ & $\begin{array}{l}\text { Cannot perform calculations } \\
\text { based on solutions found }\end{array}$ \\
\hline Test consequences & $\begin{array}{l}\text { Could not test the } \\
\text { consequences }\end{array}$ & Could not test the consequences \\
\hline
\end{tabular}




\section{Mathematics Problem Solving Auditory Subject}

a. Auditory Subject 1

At confront the problem stage, the subject is not very difficult to face problems. In addition, to understand the problem given, the subject read the problem aloud several times. At the definition of the problem, the first step taken by the subject is to draw the elbowelbow along with the long caption. Both the triangle and the long caption are written enough to define the problem. In addition, the subject writes what is known and asked from the question in the form of sentences with complete. At the discovery stage of the solution, the subject uses the Pythagoras formula to resolve the problem. The first step of the subject is to calculate the distance of the tower to ship A and the distance of the tower to ship B, or that written on the subject's answer sheet are the base and the big mat. The subject does not write Pythagoras ' formula in a common form or or. But the subject is a matter with its own language. At a stage of alleged solution consequences, the subject performs calculations based on the strategies and formulas found. The subject calculates the Port foundation distance to ship A (pedestal) and the result is 15. Furthermore, the subject calculates the distance of the Tower Foundation to ship B (big mat) and the result is 27. Then the subject calculates the ship's distance to ship B by reducing the base and the big base. But in each calculation is not written what information to find clearly. But the answers gained are correct. And at the test stage of the consequences, the subject does not write a step back checking on the answers obtained. Based on the results of the interview, the subject is rechecking for answers obtained by recalculating. The answer to the auditory subject Test 1 can be seen in Figure 3.

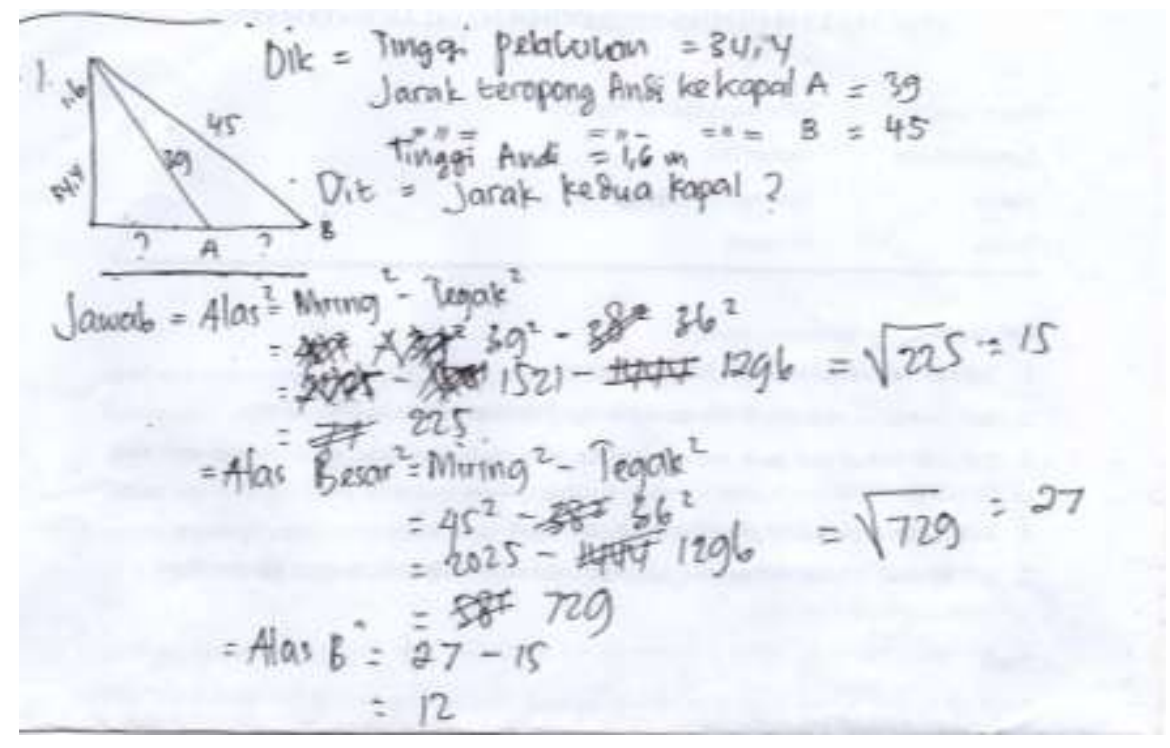

Figure 3. Auditory Subject Answer 1

b. Auditory Subject 2

At confront the problem stage, the subject feels difficulties when facing problems. This can be seen from the behaviour of the subject when faced with the question of being seen thinking long. A few minutes, the subject rereads the problem slowly. This is done several times until the subject finds a solution of the matter. At the defining stage of the issue, the subject is able to define the problem appropriately. The first step of the subject at this stage 
is to draw the angled triangle along with the length of the side. Then the subject writes the information about the question of what is known and asked sentence form. At the discovery stage of the solution, the subject uses the Pythagoras formula to resolve the problem. The subject does not write the formula in the form or but the subject directly performs calculations by substituted a known value. At a stage of alleged solution consequences, the subject performs calculations based on the strategies and formulas found. The first step done by the subject is to calculate the port foundation distance to ship A (CA). Then, the subject calculates the distance of the tower's foundation to the ship B (CB), and the last subject calculates the boat A to ship B by decreasing the CA and CB values. The answers gained are correct. And at the test stage of the consequences, the subject does not write a recheck step over the answers obtained on the answer sheet. However, based on the results of the interview, it is obtained that the subject is rechecking by re-reading the question and reviewing the answer. The answer to the auditory subject Test 2 can be seen in Figure 4.

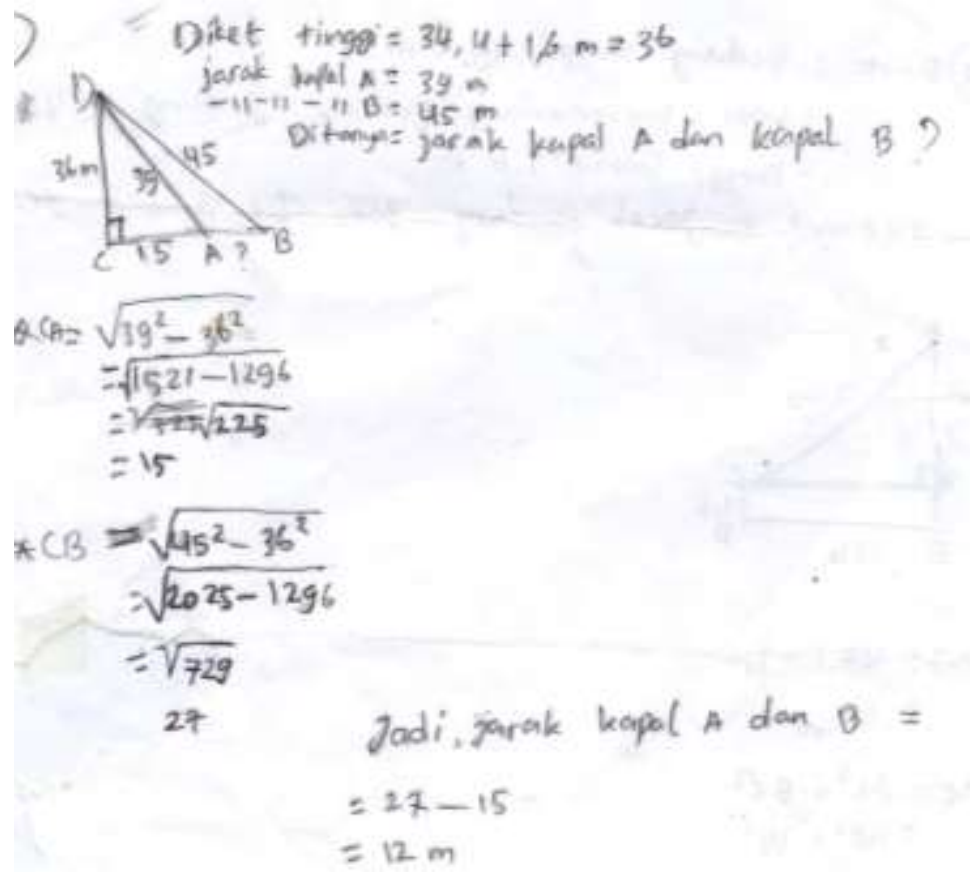

Figure 4. Auditory Subject Answer 2

Based on the analysis of the mathematical problems of the 1 and 2 auditory subjects described earlier, there could be similarities between auditory subjects in resolving the problem. The mathematical problem solving the auditory subject based on John Dewey's step can be seen in Table 4.

Table 4. Auditory Subject Mathematics Problem Solving

\begin{tabular}{|l|l|l|}
\hline \multicolumn{1}{|c|}{ Problem Solving Steps } & \multicolumn{1}{c|}{ Auditory Subject 1 } & \multicolumn{1}{c|}{ Auditory Subject 2 } \\
\hline Confront problem & $\begin{array}{l}\text { Read about several times } \\
\text { with a rather loud voice }\end{array}$ & $\begin{array}{l}\text { Read about several times with } \\
\text { a rather loud voice }\end{array}$ \\
\hline Define problem & Can define problems & Can define problems \\
\hline Inventory several solution & Can find solutions & Can find solutions \\
\hline Conjecture consequence of solution & $\begin{array}{l}\text { Can perform calculations } \\
\text { based on solutions found }\end{array}$ & $\begin{array}{l}\text { Can perform calculations } \\
\text { based on solutions found }\end{array}$ \\
\hline Test consequences & $\begin{array}{l}\text { Could not test the } \\
\text { consequences }\end{array}$ & $\begin{array}{l}\text { Could not test the } \\
\text { consequences }\end{array}$ \\
\hline
\end{tabular}




\section{Mathematics Problem Solving Kinaesthetic Subject}

At confront the problem stage, the subject seems difficult when faced with problems. After the problem is given, the subject directly reads the problem with a slow voice several times. During the test run, the subject asks for permission to the toilet three times. The subject takes a long time to be able to resolve the given issue. At the defining stage of the issue, the first step performed by the subject is to draw the $\mathrm{ABC}$ triangle. But the triangle is drawn not yet precise. The subject does not write a long caption of the triangle. At the discovery stage of the solution, the subject could not find the exact strategy and formula of the problem. This is evident from the subject's answers using a less precise multiplication strategy. Next at the alleged consequences stage of the solution, the subject performs less precise calculations. The subject does not apply a triangular image to help resolve the problem. The subject performs calculations by multiplying the known values that are and. The resulting multiplication is also less precise. And at the test stage of the consequences, the subject does not write a re-checking step towards the answers obtained. This corresponds to the interview results informing that the subject does not reexamine the answers obtained. The answer to the question of kinaesthetic subject test can be seen in Figure 5.

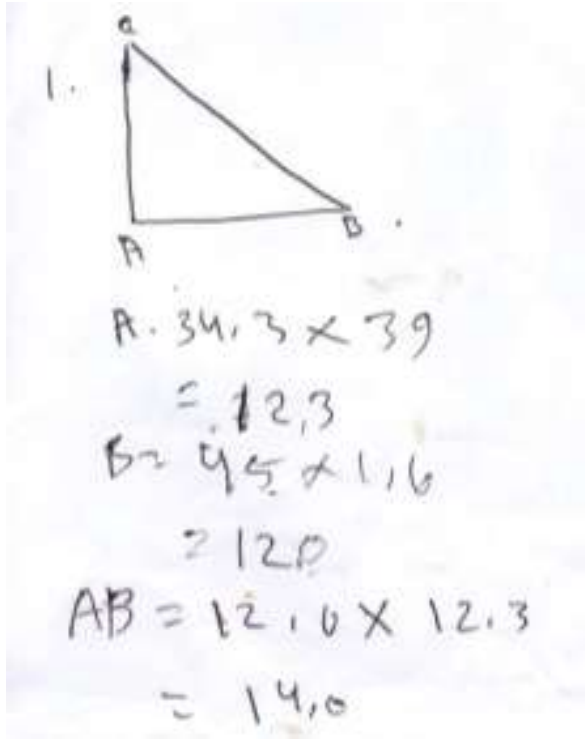

Figure 5. Kinaesthetic Subject Answer

Based on the analysis of mathematical problem-solving kinaesthetic subjects previously shown, the kinaesthetic subject steps can be summarized in resolving the problem. The mathematical problem solving kinaesthetic subject based on John Dewey's step can be seen in Table 5.

Table 5. Kinaesthetic Subject Mathematics Problem Solving

\begin{tabular}{l|l|}
\hline \multicolumn{1}{c}{ Problem Solving Steps } & \multicolumn{1}{c}{ Kinaesthetic Subject } \\
\hline Confront problem & Read about repeatedly \\
\hline Define problem & Cannot define a problem \\
\hline Inventory several solution & Could not find the right solution \\
\hline Conjecture consequence of solution & $\begin{array}{l}\text { Not able to do calculations with the right } \\
\text { strategy }\end{array}$ \\
\hline Test consequences & Could not test the consequences \\
\hline
\end{tabular}

Based on the data findings above, it was seen that at the stage faced issues of all subjects read the question repeatedly in order to understand the problems encountered. This is in 
accordance with John Dewey's troubleshooting indicators on the face of the problem. To understand the problem, auditory subjects 1 and 2 read about several times with a rather loud voice. It corresponds to the one presented by Nini Subini (2011) that the lesson material learned will be easier to understand if read aloud. In addition, at this stage kinaesthetic subject is seen often asking for permission outside the classroom several times. It is according to the characteristics of a person who is fashionable learning kinaesthetic is when bored will go or move place.

Next at the problem definition stage, the visual subject has the same tendency as the kinaesthetic subject that is unable to define the problem. According to Aries (2017), one of the factors that cause students to have difficulty at the stage of understanding the problem is that students are in a hurry or want to abbreviate time. On the other hand, auditory subjects have a tendency to define problems. Based on the interview results, the auditory subjects 1 and 2 were able to reveal what was known and asked in their own language. This is in accordance with the results of the research of Ristina Indrawati (2017) stating that the auditory subject can correctly mention what is known of the question of using its own language. Based on the results of research conducted by Sonya Eki Santoso (2016) shows that at the stage of understanding the problems, students of visual, auditory and kinaesthetic with high, moderate, and low-resolution skills are able to know the information known and asked. Based on a research interview with a visual and kinaesthetic subject, information that the subject is capable of mentioning the information known and asked by reading the because, but visual and kinaesthetic subjects do not write it on the answer sheet for a variety of reasons that are forgotten, rushed, to abbreviate the time, and the other reason is not familiar with the problem given.

Then at the discovery stage of the solution, the visual subject has the same tendency as the kinaesthetic subject that cannot find the solution of the problem given. This is different from the auditory subject that can find solutions and perform calculations based on solutions found. Sonya Eki Santoso (2011) in his research shows that at the stage of creating and implementing plans, visual and kinaesthetic students with high and moderate problem-solving capabilities and auditorial students with problem-solving capabilities are able to draw tree diagrams, identifying sub-objectives and sorting information. But in visual and kinaesthetic students with low problem solving capabilities are only able to identify sub-objectives and sort the information. Further Sonya explained that it happened because the concept of the second chance of the group is still lacking.

Visual subjects are less able to understand the problem so that the strategy/formula chosen to solve the problem is still less precise. One strategy used by the visual subject to solve the problem is to draw a triangle of elbow. It is in accordance with the opinions of Afza Bt Shafie et al. (2009) That one medium that can communicate information from students with visual learning style is to use an image. The auditory subject is generally able to find the right solution to solve the problem given. The strategy used by the auditory subject to solve is by drawing a triangular triangle and using the Pythagoras formula. Meanwhile, kinaesthetic subject is unable to find the right solution from each given problem. The strategy used by the kinaesthetic subject is a reduction and multiplication strategy, and does not offend Pythagoras ' formula. Based on research conducted by Aries Wahyu Kurniawan (2017), mentioning that students ' difficulties at the stage of designing a completion plan is due to (1) students do not understand the intent of the question, (2) students ' ability to interpret low data, and (3) weak students in remembering the formula.

At this stage of alleged solution consequences, visual subjects were unable to find a solution of a given problem. Based on this, the visual subject performs a less precise calculation so that 
the answers gained are also less precise. The auditory subject can perform calculations based on previously discovered solutions. Both auditory subjects can perform calculations based on the formulas written and the answers that are obtained are correct. And kinaesthetic subject is not able to solve the problem given so that the answers are not yet precise. This is because the subject does not understand the problem given.

And at the test stage the consequences, visual subjects, auditory subjects, and kinesthetic subjects both do not re-check the answers obtained. This is different from the research results done by Ristina Indrawati (2017) which suggests that at the stage of solving the fourth Polya (Looking Back), visual subject, auditory subject, and kinaesthetic subject are able to re-examine the answer by counting back with reverse operation. Based on the results of the interview, the visual subject rechecks the answers gained by re-reading the questions and recounting them. This is in accordance with the research conducted by Ristina Indrawati (2017) stating that to check the answers obtained, the visual subject reads repeatedly the information that is considered important that is in question. While written on the answer sheet, both visual subjects 1 and 2 are not seen checking the answers obtained. According to Septiyan et al. (2015), the student's weakness in the re-examining stage is because students are more stuck in the way taught by their teachers without developing their own ways to solve a problem.

In another study, Sulistiyorini (2016) mentions that the location of difficulties of students at the re-examining stage is because the students do not know how to look back correctly. Most students are just as limited as reread the answer and not associating whether the answer is up to the question. Further Sulistiyorini mentions that students need to do a lot of practice. Therefore, students will be accustomed to completing the problem with the correct solving steps.

\section{CONCLUSION AND SUGGESTIONS}

Based on the analysis and discussion in this study, can be concluded that the student math problem solving based on John Dewey's step is reviewed from the Learning style is: (1) The visual subject in the face of problems with reading the problem repeatedly, able to define the problem correctly, unable to find the right solution so that the calculations and answers obtained is not appropriate, and not able to test the consequences, (2) the subject of the , able to define the problem properly, able to find the right solution so that the calculations and answers obtained are also appropriate, and not able to test the consequences, and (3) kinaesthetic subject facing problems by reading the problem several times, able to define the problem correctly, unable to find the right solution so that the calculations and answers gained are not appropriate, and unable to test the consequences.

\section{REFERENCES}

Aries W.K. (2017). Analisis Kesulitan Siswa dalam Pembelajaran Matematika pada Materi Peluang Kelas X SMK Muhammadiyah 4 Surakarta. (Skripsi). Universitas Muhammadiyah Surakarta, Surakarta.

Carson, Jamin. (2007) A Problem with Problem Solving: Teaching Thinking without Teaching Knowledge. The Mathematics Educator Journal, 17(2), 7-14.

Hartono, Yusuf. (2014). Matematika: Strategi Pemecahan Masalah. Yogyakarta: Graha Ilmu.

I Putu E.I., dkk. (2016). Faktor-Faktor yang Mempengaruhi Kemampuan Pemecahan Masalah Matematika: Pengetahuan Awal, Apresiasi Matematika, dan Kecerdasan Logis Matematis. Seminar Nasional MIPA, Singaraja.

Indriwati, Ristina. (2017). Profil Penyelesaian Masalah Matematika Ditinjau dari Gaya Belajar. Jurnal Program Studi Pendidikan Matematika, 3(2), 91-100.

National Council of Teachers of Mathematics. (2000). Prinsiples and Standards for School Mathematics (PSSM). Reston: NCTM.

Rahmawati, Fitria. (2016). Pengaruh Gaya Belajar dan Perhatian Siswa terhadap Kemampuan Memecahkan Masalah Matematika. (Skripsi). UM Surakarta, Surakarta.

Septiyan, Hobri dan Fatahilah. (2015). Penerapan Pembelajaran Pemecahan Masalah Model Polya untuk Menyelesaikan Soal-Soal Aplikatif Pokok Bahasan Segi Empat pada Siswa kelas VII F SMPN 9 Jember Semester Genap Tahun Ajaran 2013/2014. Kadikma, 6(2), 63-74. 


\section{0 | IJECA (International Journal of Education and Curriculum Application)}

Vol. 2, No. 2, August 2019, pp. 20-30

Shafie, A.B., Janier, J.B., Ahmad, W.F. (2009). Visual Learning in Application and Integration, Visual Informatics: Bridging Research and Practice.

Sonya E.S. (2016). Analisis Kemampuan Pemecahan Masalah Berdasarkan Gaya Belajar Melalui Pembelajaran Problem Based Learning (PBL) Berbasis Quantum Learning. (Skripsi). Universitas Negeri Semarang, Semarang.

Subini, Nini. (2011). Rahasia Gaya Belajar Orang Besar. Yogyakarta: Javalitera.

Suci A., Yusuf H., dan Cecil H. (2017). Kemampuan Pemecahan Masalah Matematika Siswa pada Pembelajaran Matematika Menggunakan Strategi Abduktif-Deduktif di SMAN 1 Indralaya Utara. Jurnal Elemen, 3(1), 25-34.

Sulistiyorini. (2016). Analisis Kesulitan Siswa dalam Pemecahan Masalah Soal Cerita Matematika Siswa SMP Universitas Muhammadiyah Surakarta. (Skripsi). Universitas Muhammadiyah Surakarta, Surakarta.

Syaharuddin. (2016). Deskripsi Kemampuan Pemecahan Masalah Matematika dalam Hubungannya dengan Pemahaman Konsep Ditinjau dari Gaya Belajar Siswa Kelas VIII SMPN 4 Binamu Kabupaten Jeneponto. (Tesis). Universitas Negeri Makassar, Makassar.

Vina M.R., Edi Y., dan Asep N. (2017). Kemampuan Pemecahan Masalah Siswa Berdasarkan Teori John Dewey pada Materi Trigonometri. Jurnal Pendidikan dan Pembelajaran Khatulistiwa, 6(7), 1-8.

Yaumi, Muhammad. (2013). Prinsip-Prinsip Desain Pembelajaran. Jakarta: Kencana Prenada Media Grup.

Youwanda L. dan Jailani. (2015). Analisis Proses Penyelesaian Masalah Matematika Siswa Sekolah Menengah Pertama. Jurnal Riset Pendidikan Matematika, 2(1), 148-161. 